\title{
Assessment of Metals in Soils around Automobile Workshops in Ilorin NC Nigeria
}

\author{
Saheed Oke ${ }^{1}$, Fausat M'civer' ${ }^{2}$, \\ ${ }^{1}$ Civil Engineering Department, Central University of Technology, Bloemfontein, South Africa \\ soke@cut.ac.za; mciverf@yahoo.com \\ ${ }^{2}$ Chemical and Geological Department, Al-Hikmah University \\ Adewole, Ilorin, Nigeria
}

\begin{abstract}
The paper assesses the presence of metals in soils around automobile workshops in Ilorin Nigeria. Automobiles workshops are becoming points of pollution concerns to the environments. Core samples were obtained from five automobile workshops site at a different part of the city. Hand auger was used in obtaining the samples. Both the contaminated topsoil and uncontaminated subsoil section was obtained. Majors and trace metals were analysed for the soil samples using XRF machines. Soil mineralogical composition was analysed using XRD. Other analyses carried out on the soil samples are soil pH and grain sizes composition. Results show the compositions of major oxides are silica, alumina and iron oxides while minors composition include potassium, sodium and manganese oxides. Zinc, arsenic and vanadium are the major trace metals contaminants in the soil. Soil pH shows a slightly acidic to neutral. Sources of trace metals in the soils of automobiles workshop are worn-out parts, metal craps, zinc paints, steel alloys in crankshaft and gears and packaging materials. The assessment has shown that automobile workshops introduces heavy metals pollutions into soils and they are a major source of environmental pollution.
\end{abstract}

Keywords: Automobile workshop, trace metals, soil, Ilorin city, zinc.

\section{Introduction}

Ilorin just like other typical city in developing economies is increasingly becoming urbanised and overpopulated. The population explosion had increased the use of automobiles and automobiles workshop in the city. Automobiles workshops forms anthropogenic point source contaminant dispersion, which are cause for public concern. Heavy metals in soils have tendency to contaminant water bodies (surface and groundwater). Heavy metals are known to be toxic and some nonbiodegradable [1]. Utang et al. [2] noted that aautomobiles wastes including solvents, paints, hydraulic fluids, lubricants and stripped oil sludge contribute to the high amount of metals found in the soils. Other contaminants waste from worn-out parts, metal craps, used batteries and packaging materials.

Adewale and Echegbu [3] opined that automobiles workshop and its activities constitute one of the major sources of increasing metals concentrations in Nigeria ecosystems. The aim of the study is therefore to establish the level of major and trace metals contaminant release into the environment by the anthropogenic activities at automobile workshops. It is hoped that the study would provide additional scientific literatures to the existing body of knowledge on the impact of automobile workshops on soil around its location. It is also hope to sensitize the general public on automobile workshop contamination, its control and further monitoring of the metals and heavy metal accumulated in soils. Recent studies on automobiles on soils and environments include the work of Pam et.al [4] in Benue region and Iwegbue [5] on automobile waste dumps at Portharcourts city.

\section{Materials and Methods}

This investigation was carried out within five automobile workshops in Ilorin metropolis in Kwara State. Kwara is located within the northern central geopolitical zone commonly referred to as the middle belt. Ilorin is the state capital of Kwara State in North Central Nigeria. The city is located on latitude $8^{\circ} 30^{\prime}$ and $8^{\circ} 50^{\prime} \mathrm{N}$ and longitude $4^{\circ} 20^{\prime}$ and $4^{\circ} 35^{\prime} \mathrm{E}$ of the equator. Ilorin metropolis experiences two climatic seasons i.e. rainy and dry season. The city geologically is located on Basement rocks of SW Nigeria. The rock types include gneiss, migmatite, schist and granitic rocks. Soils derived from these suits of rocs includes clay, gravel and sand. 
The workshops used in this study were chosen from different sites so as to cover the different geology and soil types. Five different samples were taken from different regions of Ilorin metropolis. The sampling points locations and labels are:

Sample A - Odota Area

Sample B - Ipata Oloje

Sample C - Taiwo Area

Sample D - Offa Garage

Sample E - Sango Area

Core sample from the contaminated automobile site were taken by drilling about $10 \mathrm{~cm}-20 \mathrm{~cm}$ into the ground, so as to be able to get the layer of both affected and unaffected soil profile from each locations. Samples were collected inside labeled polythene bags. Figure 1 shows example of sample collected from automobile workshops. Identification of the major and traces metals using XRD and XRF analysis were carried out with the aid of the panalytical empryean $\mathrm{x}$-ray diffractometer and panalytical axios xrf machine at Geology laboratory of University of Free State South Africa. The instrument's settings and operation condition were done in accordance with manufacturer's specification.

Soil samples were air and sun-dry for 48 hours, then pulverized and sieved. Then analysed in the laboratory using standard techniques. Grain size analysis was carried out on the samples using mechanical sieve method to determine the distribution of the coarser and fine particles. This was carried out making through a mechanical shaker. The soil samples were carefully poured into the top sieve and it was covered by the cap. The sieve stack was placed in the mechanical shaker and shaken for 10 minutes. The stack was removed after 10 minutes and the weight of each sieve with its retained soil weighed and recorded. Data analysis was done and from the data analysis the percentage distribution of the gravel, sand and fines was obtained.

The soil PH for the different soil samples was obtained using slurry method. The procedure includes taking 20 grams of the homogenous soil samples and equal amount of distilled water in a ratio of 1:1. The mixture was stirred for few minute and was allowed to sit for 15 minutes, the stirring was started again after 15 minutes and readings was taken and recorded with the aid of a $\mathrm{pH}$ meter.

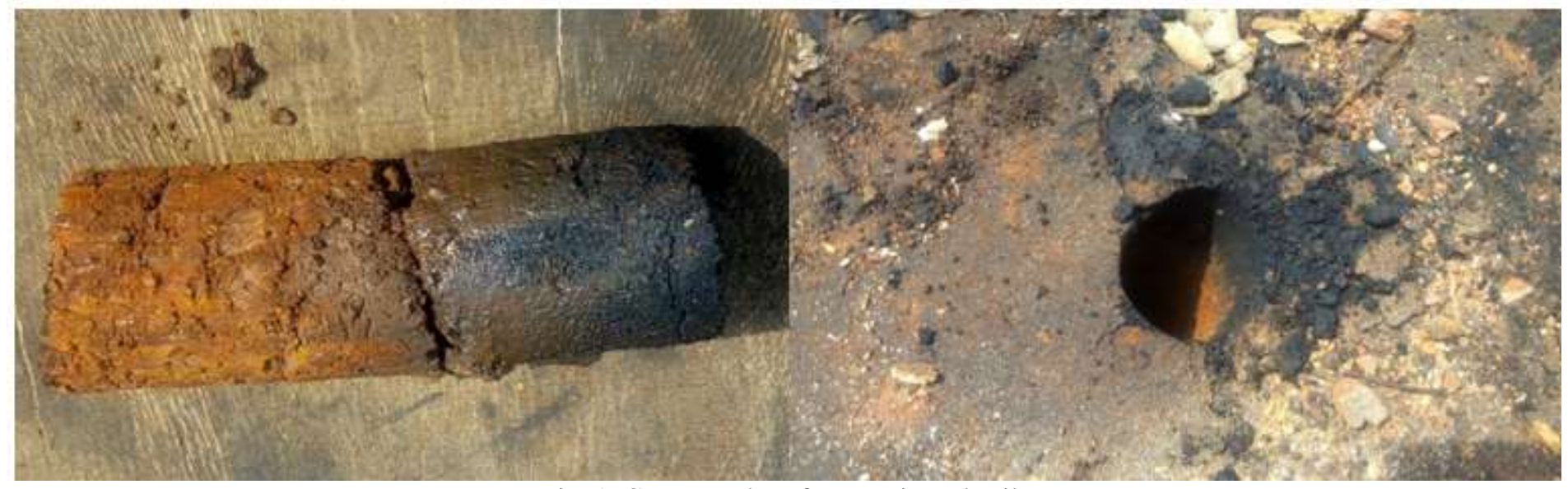

Fig. 1: Core samples of contaminated soil.

\section{Results and Discussion}

The result of major metals in soil is presented in Table 1. Silica concentration for sample A, B, C, D and E are 83.1, 69.1, 69.3, 66.6 and 74.83. Aluminium oxides from sample A to E are 3.9, 5.2, 11.0, 8.4, 6.78 respectively. Iron oxide concentrations are 4.7, 8.4, 3.5, 8.0, 3.84 for sample A, B, C, D and E respectively. The major metals and their oxides results show silica to be the dominant elements. This is followed by minor amount of aluminium and iron oxides elements with concentration below $10 \mathrm{ppm}$ except for sample B with aluminium oxide of $11 \mathrm{ppm}$ (Table 1). The major metals results show more of natural rock compositions and geogenic activities than contaminations. This could mean that metals from automobile workshop has not impacted the major metals as much to change its compositions. However, 
the trace metals compositions indicate higher concentration of zinc, arsenic and vanadium. $\mathrm{pH}$ value of sample $\mathrm{A}, \mathrm{B}$ and $\mathrm{E}$ is neutral while that of sample $\mathrm{C}$ is slightly acidic and sample $\mathrm{D}$ is slightly alkaline.

Table 1: Major metals present in soils from automobile workshop. Samples are in ppm.

\begin{tabular}{|c|c|c|c|c|c|}
\hline Major Metals & A & B & C & D & E \\
\hline $\mathrm{SiO}_{2}$ & 83.1 & 69.1 & 69.3 & 66.6 & 74.83 \\
\hline $\mathrm{TiO}_{2}$ & 0.4 & 1.0 & 0.4 & 0.4 & 0.48 \\
\hline $\mathrm{Al}_{2} \mathrm{O}_{3}$ & 3.9 & 5.2 & 11.0 & 8.4 & 6.78 \\
\hline $\mathrm{Fe}_{2} \mathrm{O}_{3}$ & 4.7 & 8.4 & 3.5 & 8.0 & 3.84 \\
\hline $\mathrm{MgO}$ & 0.4 & 0.5 & 1.2 & 0.3 & 0.13 \\
\hline $\mathrm{MnO}$ & 0.1 & 0.1 & 0.1 & 0.1 & 0.05 \\
\hline $\mathrm{CaO}$ & 0.4 & 2.9 & 1.1 & 1.2 & 1.24 \\
\hline $\mathrm{Na}_{2} \mathrm{O}$ & 0.0 & 0.2 & 0.4 & 0.0 & 0.34 \\
\hline $\mathrm{K}_{2} \mathrm{O}$ & 0.6 & 1.1 & 3.8 & 2.8 & 3.16 \\
\hline $\mathrm{P}_{2} \mathrm{O}_{5}$ & 0.1 & 0.1 & 0.1 & 0.1 & 0.08 \\
\hline $\mathrm{LOI}$ & 8.8 & 14.0 & 10.7 & 12.4 & 6.19 \\
\hline $\mathrm{pH}$ & 6.8 & 7.0 & 6.3 & 7.5 & 7.0 \\
\hline
\end{tabular}

Zinc is released to soil at the automobile workshop in the form of zinc oxide as zinc paints. Zinc paints is an additive to lubricate oil [6] and its fond to be common problems to automobile workshops in Nigeria [3, 4]. Sample B present the highest zinc concentrations of $839 \mathrm{ppm}$ while other samples with high concentration are sample E (342 ppm) and sample D (388 ppm). Zirconium concentration is highest in sample B with $2558 \mathrm{ppm}$ and lowest in sample A which show 800 ppm. Zirconium is found in soils and resistance to corrosion. The higher concentrations in automobile soils could be from the steel alloys, abrasives and filaments. The soil $\mathrm{pH}$ ranges from 6.3 (slightly acidic) in sample $\mathrm{C}$ to 7.5 in sample $\mathrm{D}$. Soil $\mathrm{pH}$ is known to influence mobility of metal in water and soil. Vanadium is a rare element but its source in the automobile workshop may be due to its steel additive nature. Steel alloys used in crankshaft, axles and gears found in automobile workshops are other sources of vanadium in soils samples. Vanadium soil concentrations increases from sample C and D at $48 \mathrm{ppm}$ and 44 ppm to sample B at $39 \mathrm{ppm}$ and lowest in sample A and E with $13 \mathrm{ppm}$ and $19 \mathrm{ppm}$ respectively. Sc is below detection limit in sample A and D while sample B, C and E shows concentrations of $11 \mathrm{ppm}, 6 \mathrm{ppm}$ and 5 ppm respectively. Arsenic is considered as both metals and metalloid. Arsenic concentration is low in all the sample with highest arsenic concentration of 9 ppm in sample B.

Table 2: Trace metals concentrations in the five samples from automobile workshop.

\begin{tabular}{|c|c|c|c|c|c|}
\hline Trace element & A & B & C & D & E \\
\hline Zn (ppm) & 155 & 839 & 289 & 388 & 342 \\
\hline As (ppm) & 6 & 9 & 3 & 5 & 6 \\
\hline $\mathrm{Rb}(\mathrm{ppm})$ & 17 & 25 & 56 & 58 & 56 \\
\hline $\mathrm{Zr}(\mathrm{ppm})$ & 800 & 2558 & 2170 & 1216 & 2063 \\
\hline $\mathrm{U}(\mathrm{ppm})$ & 1 & 1 & 3 & 2 & 3 \\
\hline $\mathrm{Sc}(\mathrm{ppm})$ & $\mathrm{BDL}$ & 11 & 6 & $\mathrm{BDL}$ & 5 \\
\hline $\mathrm{V}(\mathrm{ppm})$ & 13 & 39 & 48 & 44 & 19 \\
\hline
\end{tabular}

XRD results shows the mineralogical compositions of the soil materials to include quartz, $\mathrm{k}$-feldspar, plagioclase feldspars, kaolinite in major abundant and minor calcite and mica. Results shows metals are more likely to contaminate the top soils around the automobile workshop than the subsequent layers. This is due more to the filtering capacity of the soil layers to retain the metals [7] as shown in Figure 1. Soils from location B shows the soil layer with the highest water content (LOI) with highest arsenic and zinc concentrations levels (Table 2).

The particle size distribution puts the soil in sandy to loamy textural classification. The properties are typical of soil in the area. Sand content is highest in sample E and lowest in sample B. Gravel has the highest concentration in sample D and 
lowest in sample E while the highest fine was recorded in sample B and lowest in sample D. From the grain size analysis, the percentage distribution of the gravel, sand and fine of the five samples are as follows:

For sample A: \% gravel $=14.75, \%$ sand $=79.78, \%$ fine $=2.45$.

For sample B: $\%$ gravel $=10.82, \%$ sand $=77.35, \%$ fine $=11.83$.

For sample C: $\%$ gravel $=15.94, \%$ sand $=82.02, \%$ fine $=2.01$.

For sample D: \% gravel $=22.07, \%$ sand $=77.89, \%$ fine $=0.29$.

For sample E: $\%$ gravel $=5.87, \%$ sand $=90.13, \%$ fine $=3.85$.

\section{Conclusion}

The soil assessment show that automobile workshop impacts the environments by contaminating the soils around the workshops with heavy metals of Vanadium, Arsenic and Zinc. Majors sources of contaminant in the automobile workshops are steel alloys used in crankshaft, axles and gears and zinc paints in additive lubricate oil. Soil $\mathrm{pH}$ assist the release of these metals in soils. Arsenic concentrations are generally low which means the automobile workshop has less impact on the soils. The high sand content in sample D is responsible for the highest aluminium oxides present in the sample. There are no soil contaminations from the major metals present in the study area.

\section{Acknowledgements}

The author wishes to acknowledge the contributions of Mr Aberi Ridwan Ayodeji and Mr Ahmed both students of Al-Hikmah University Ilorin Nigeria.

\section{References}

[1] K. M. Mohiuddin, H. M. Zakir, K. Otomo, S. Sharmin and N. Shikazono, "Geochem distribution of trace metal pollutants in water and sediments of downstream of an urban river," Int. J. Environ. Sci. Tech., vol. 7, no. 1, pp. 1728, 2010.

[2] P. B. Utang, O. S. Eludoyin, and C. L. Ijekeye, "Impacts of automobile workshops on heavy metal concentrations of urban soils in Obio/Akpor LGA, Rivers state, Nigeria," African Journal of Agricultural Research, vol. 8, no. 26, pp. 3476-3482, 2013.

[3] M. B. Adewole, and L. U. Uchegbu, "Properties of Soils and plants uptake within the vicinity of selected Automobile workshops in Ile-Ife Southwestern Nigeria," Ethiopian Journal of Environmental Studies and Management, vol. 3, no. 3, 2010.

[4] A. A. Pam, R. S. Ato and J. O. Offem, "Contribution of automobile mechanic sites to heavy metals in soil: a case study of North Bank Mechanic Village Makurdi, Benue State, Central Nigeria," J. Chem. Bio. Phy. Sci. Sec. D, vol. 3, no. 3, pp. 2337-2347, 2013.

[5] C. M. Iwegbue, "Metal fractionation in soil profiles at automobile mechanic waste dumps around Port- Harcourt," Waste Manage. Res., vol. 25, no. 6, pp. 585-593, 2007.

[6] D. C. Adriano, Trace elements in the terrestrial environment. Springer-Verlag, 2nd (Edn.), NY, pp. 324, 2001.

[7] P. C. Onianwa, O. M. Jaiyeola and R. N. Egekenze, "Heavy metal contamination of topsoil in the vicinities of autorepair workshops, gas stations and motor parks in a Nigerian city," Toxicol. Environ. Chem., vol. 84, no. 1-4, pp. 3339, 2001. 